\title{
THE MINERAL CONSUMPTION AND WEIGHT GAIN OF GRAZING STEERS FED MINERAL SUPPLEMENTS WITH DIFFERENT SODIUM CONTENTS AND PHYSICAL FORMS
}

\author{
CONSUMO MINERAL E GANHO DE PESO DE GARROTES MANTIDOS EM PASTOREIO \\ RECEBENDO SUPLEMENTOS MINERAIS COM DIFERENTES \\ TEORES DE SÓDIO E FORMAS DE APRESENTAÇÃO
}

\author{
Enrico Lippi Ortolani ${ }^{1}$
}

\section{SUMMARY}

Thirty crossbred two-year-old steers, kept on pasture of Braquiaria decumbens, were used in two different experiments of 90 days each. In the first experiment, the steers were randomly assigned in five groups of six steers each to verify the influence of different percentages of sodium chloride (SC) in mineral mix (MM) containing essential macro and microelements (A - $100 \%$ SC; B - 80\% SC/20\% MM; C - 60\% SC/40\% MM; D $40 \%$ SC/ 60 MM and E - 20\% SCl/80 MM) on the consumption of the mineral supplement and the weight gain. In the second experiment, the same steers were reassigned to three groups of 10 animals each to study the effect of mineral salt $140 \%$ SC/60\% MM) offered loose, partially blocked or as a hard block on the mineral consumption and weight gain. Steers fed supplement D had the highest intake followed by groups B and C; lowest intake was verified in group E. All mineral supplements but $E$ were fed adequately to meet the $\mathrm{Na}$ requirement $(6.3 \mathrm{~g} / \mathrm{head} / \mathrm{d})$ for a $350 \mathrm{~kg}$ growing steer. Higher average daily gain was verified in steers of groups $D$ and $C$ than those of group E. The highest mineral intake was observed in steers fed loose mineral (60g/head/d) followed by partially block $(45 \mathrm{~g} / \mathrm{d})$; the lowest consumption occurred in the steers fed hard block mineral $(27 \mathrm{~g} / d)$. The coefficient of variation of supplement intake increased as mineral hardness increased. The higher the mineral intake, in the second experiment, the greater the average daily gain. Grazing steers should be offered mineral supplements with $40 \%$ and $60 \%$ of $\mathrm{NaCl}$ changed weekly in order to avoid the hardening of its contents.

Key words: mineral supplement, cattle, sodium, intake, physical form, weight gain, pasture.

\section{RESUMO}

Trinta garrotes cruzados, com dois anos de idade, mantidos em pastos de capim Braquiria decumbens, foram utilizados em dois experimentos, com duração de 90 dias cada.

\begin{abstract}
No primeiro deles, os garrotes foram distribuídos, ao acaso, em cinco grupos de seis animais cada, para avaliar a influência de diferentes porcentagens de cloreto de sódio (CS) na mistura mineral (MM), contendo os principais macro e microelementos essenciais, (A - 100\% CS; B - 80\% CS/20\% MM; C - 60\% CS/40\% MM; D - 40\% CS/ 60\% MM; E - 20\% CS/80\% MM) sobre o consumo de suplemento mineral e o ganho de peso, no período. No segundo experimento, os mesmos garrotes foram redistribuídos, ao acaso, em três grupos de 10 animais cada, para verificar a influência da oferta de suplemento mineral na forma solta, parcialmente empedrado ou totalmente empedrado, sobre o consumo deste alimento e sobre o ganho de peso, no período. No primeiro experimento, maior ingestão de suplemento foi detectada no grupo recebendo a fórmula $D$, seguida pelas fórmulas $B$ e $C$; menor ingestão ocorreu nos garrotes que receberam o suplemento E. Com exceção deste último grupo, o suplemento mineral dos demais foi ingerido adequadamente para suprir o requerimento diário de sódio (6,3g/cabeça) de um garrote de $350 \mathrm{~kg}$. Maior ganho de peso médio diário foi constatado em garrotes dos grupos $D$ e C, comparados com os do grupo $E$. No segundo experimento, maior ingestão de suplemento ocorreu em garrotes que receberam mineral solto (60g/cabeça/dia), seguido pelos que ingeriram sal mineral parcialmente empedrado (45g/dia); o menor consumo foi constatado nos garrotes para os quais foram ofertados suplemento empedrado (27g/dia). O coeficiente de variação da ingestão do suplemento mineral, pelos garrotes, aumentou quanto maior foi o grau de empedramento do sal oferecido. Quanto maior foi a ingestão de suplemento mineral, ofertada aos garrotes no segundo experimento, maior foi $o$ ganho de peso constatado. Os dados obtidos permitem concluir que garrotes em pastoreio devem receber suplementos minerais contendo $40 \%$ a $60 \%$ de cloreto de sódio nas suas fórmulas, e que os mesmos devem ser reabastecidos semanalmente, nos cochos, a fim de evitar o empedramento de seus conteúdos.
\end{abstract}

Palavras-chave: suplemento mineral, bovino, sódio, ingestão, forma física, ganho de peso, pastagem.

\footnotetext{
${ }^{1}$ Médico Veterinário, MSC, PhD., Professor, Departamento de Clínica Médica da Faculdade de Medicina Veterinária e Zootecnia, Universidade de São Paulo, Av. Prof. Dr. Orlando Marques n87. "Cidade Universitária”, 05508-000, São Paulo S.P., Brazil. 


\section{INRODUCTION}

Most brazilian beef and dairy cattle are raised in extensive conditions depending almost exclusively on pasture intake to obtain the essential nutrients required for maintenance, production and reproduction. Nevertheless, the tropical and subtropical forage species are frequently poor in some essential macro and microelements to cattle, such as sodium, phosphorus, sulphur, copper, zinc, cobalt, selenium, etc. Many reports have demonstrated the beneficial effects of supplementing deficient macro and microelements on overall production of cattle fed mainly tropical forages (MORRIS, 1980; McDOWELL et al. 1984; TOKARNIA et al., 1988; CAVALHEIRO \& TRINDADE, 1992; McDOWELL et al (1993). It is widely recommended that mineral supplements be offered ad libitum in feed troughs to cattle. However, many factors interfere with the satisfactory consumption of mineral supplements by cattle. This matter was reviewed by PAMP et $\boldsymbol{a l}$. (1976), McDOWELL et al. (1993) and TAIT \& FISCHER (1996). Among the factors cited by these authors soil fertility, forage type and quality, physiological state of cattle such as growth, pregnancy and lactation, location and easy of access of the mineral feed troughs, content of protein and energy of the diet and season of the year were considered. Nevertheless, the most important factors were the palatability and the physical form of the mineral supplement offered to cattle. The sodium content plays the most important role to stimulate cattle to consume mineral supplement (DEW et $\boldsymbol{a l}$. 1954, PAMP, 1976). Mammals have an instinctive liking for sodium chloride. DEW et al. (1954) allowed dairy cows free access to various mixtures of sodium chloride and steamed bone meal and concluded that the cows showed a clear preference for mixture with high sodium content. Recently, TAIT \& FISHER (1996) also stated the importance of sodium content as the principal controller of mineral supplement intake, although they have suggested further studies to verify the effect of different ratio of common salt to mineral mix on the consumption of mineral supplement by cattle.

The hardening of the mineral supplement in the feed trough can depress its consumption by cattle. This is caused by the tendency of some minerals, principally sodium chloride, to absorb gradually and to retain moisture from the air and the rain. McDOWELL et al. (1993) stated that cattle offered minerals as a hard block can have the intake depressed by $10 \%$. However, ROCKS et al. (1982) studied, in two experiments, the consumption of loose and block minerals by sheep and verified that the mean intake of loose mineral were 7.2 and 2.3 higher, respectively in the first and second experiments, than that consumed as a block. Moreover, ROCK et al (1982) observed a greater uniformity in intake of loose mineral instead of block salt. The discrepancy of results suggests further studies of the effect of physical form of mineral salt offered to cattle on its consumption.

The objective of this study was to evaluate the influence of different percentages of sodium chloride in mineral mix and the offering of three different physical forms of mineral supplement on the consumption of mineral and weight gain of steers.

\section{MATERIAL AND METHODS}

Thirty crossbred two-year-old charolais $\mathrm{x}$ nelore steers were used in both trials. All animals were kept for the last six months before the beginning of the experiment in several paddocks of Braquiaria decumbens and were supplied with minerals offered free-choice with the following formula per kilogram: dicalcium phosphate $486 \mathrm{~g}$, sodium chloride 400g, elemental sulphur 20g, magnesium oxide $30 \mathrm{~g}$, Zinc 3,600ppm, Copper $1,500 \mathrm{ppm}$, Iron 1,800ppm, Manganese 1,300ppm, Cobalt 200ppm, Iodine $150 \mathrm{ppm}$, Selenium 12ppm. One month before the beginning of both experiments the animals were treated with anthelmintic (avermectin) and vaccinated against foot-and-mouth disease.

First Experiment - Thirty steers were blocked by initial weight. Within each block, the animals were randomly assigned to one of the five paddock groups with six steers each. The two hectare paddocks were well-established pastures of Braquiaria decumbens with the similar biomass and chemical composition (table 1). Fertilizer $(22.5 \mathrm{~kg}$ nitrogen/hectare) was applied 30 days before the beginning of the experiment. A covered mineral feeding trough $(2 \mathrm{~m}$. long $\mathrm{x} 40 \mathrm{~cm}$. width $\mathrm{x} 30 \mathrm{~cm}$ deep) and drinking facility were available within each paddock. Mineral feeding troughs were located at the opposite end to the water to encourage animals to graze the entire pasture area. Five paddock groups were each randomly assigned to the following treatments: $100 \% \mathrm{NaCl} ; 80 \% \mathrm{NaCl} / 20 \%$ mineral mix; $60 \% \mathrm{NaCl} / 40 \%$ mineral mix; $40 \% \mathrm{NaCl} /$ $60 \%$ mineral mix and $20 \% \mathrm{NaCl} / 80 \%$ mineral mix. Each kilogram of the mineral mix contained dicalcium phosphate $650 \mathrm{~g}$, limestone $230 \mathrm{~g}$, dried molasses $20 \mathrm{~g}$, elemental sulphur $30 \mathrm{~g}$, magnesium oxide $40 \mathrm{~g}$ and trace element premix $30 \mathrm{~g}$. Every 
Table 1 - Average chemical composition ( \%) of Braquiaria decumbens grass of the paddocks used in both experiments.

\begin{tabular}{lcc}
\hline (\%) & $\begin{array}{c}\text { Experiment } \\
1 *\end{array}$ & Experiment $2 * *$ \\
& & \\
\hline & & \\
Dry Matter & 33.8 & 27.6 \\
Crude Protein & 8.2 & 12.2 \\
Ash & 7.2 & 6.5 \\
Acid Detergent Fibre & 35.3 & 29.5 \\
Neutral Detergent & 77.7 & 72.3 \\
Fibre & 2.2 & 2.1 \\
Ether Extract & 0.38 & 0.25 \\
Calcium & 0.09 & 0.14 \\
Phosphorus & 0.01 & 0.012 \\
Sodium & 0.17 & 0.20 \\
Sulphur & & \\
& & \\
\hline Mean of 12 &
\end{tabular}

* Mean of 12 samples collected from all utilized paddocks. ** Mean of 8 samples collected from all utilized paddocks.

week at least $3,000 \mathrm{~g}$ of the respective $\mathrm{NaCl} /$ Mineral mix supplement was provided into the feeding trough to each paddock. The amount of supplement remaining in the feed trough was weighted weekly to know the mineral consumption. Animals were weighted monthly and at beginning and the end of the experiment. Access to water and pasture was denied for 16-h prior to each of these weightings. This experiment started at September $15^{\text {th }}$ and finished at December $15^{\text {th }}$ of 1995 .

Second Experiment - The same thirty animals were reused in the second experiment after blocking by initial weight and being randomly assigned to one of the three paddock groups with 10 steers each. Three paddocks previously used were again fertilized with $22.5 \mathrm{~kg}$ nitrogen/hectare 30 days before the beginning of the experiment. The biomass and the chemical composition (table 1) of Braquiaria decumbens in the three paddocks were similar. It was used in all treatments the $40 \% \mathrm{NaCl} /$ $60 \%$ mineral mix formula previously described. The mineral supplement was prepared and divided in three different portions to be used. To the first group the mineral supplement was offered loose and each five days its whole content was changed to a new portion; the supplement was not allowed to block whatsoever. The second group received a mineral supplement that was previously sprayed with water to produce small solid mineral stones of three to five $\mathrm{cm}$ of diameter each; the mineral supplement was changed every fortnightly. To the remaining group, the mineral supplement was offered as a single solid block; for that the mixture was previously placed in the feeding trough and thereafter thoroughly wetted and left dry to become a hard block; the mineral supplement was changed three times throughout the experiment. This last group simulated the condition often found under extensive management when excessive amount of mineral supplement is deposited in the feed trough at once, principally during the rainy season, and there is a tendency to become hard when exposed to moisture. The amounts of mineral supplement remaining in the feed trough were measured every time there was a change in its content to determine group mineral consumption during each interval. Body weight was measured as described in the first experiment. This experiment started at January $15^{\text {th }}$ and finished at $15^{\text {th }}$ April of 1996.

Standard methods were used for determination of chemical composition of the samples of Braquiaria decumbens grass collected in both experiments (AOAC.,1985). Differences between and within treatments were compared by analysis of variance with application of the Duncan's multiple range test to compare the means (SNEDCOR \& COCKRAM, 1967) .

\section{RESULTS}

First Experiment - The influence of $\mathrm{NaCl}$ content in the mineral supplement on the mineral consumption and average daily gain throughout the experiment by the steers is expressed in table 2 . The use of $40 \%$ of sodium chloride in the formula produced the highest mineral intake $(\mathrm{p}<0.05)$ followed by the use of $60 \%$ and $80 \% \mathrm{NaCl}$; the lowest mineral consumption was obtained with $20 \%$ $\mathrm{NaCl}$. Average daily gain throughout the experiment was higher $(\mathrm{p}<0.05)$ for the $40 \% \mathrm{NaCl}$ and the $60 \%$ $\mathrm{NaCl}$ groups than the $100 \%$ and $20 \% \mathrm{NaCl}$ groups.

Second Experiment - The influence of the form in which the mineral supplement was offered on the mineral consumption and average daily gain throughout the experiment by the steers is expressed in the table 3 . The highest mineral intake was observed in steers that consumed mineral supplement offered loose and changed frequently ( $\mathrm{p}$ $<0.01$ ); followed by the mineral not completely hard and changed fortnightly; the lowest mineral intake occurred in steers that ingested mineral supplement offered as a hard block and changed sporadically. Similar results were obtained with the average daily gain. Higher average daily gain was obtained in steers consuming loose mineral mix $(\mathrm{p}<0.05)$ followed by the mineral not completely hard and changed fortnightly; the steers having mineral supplement offered as a hard block had the lowest average daily gain. 
Table 2 - Influence of the sodium chloride content in the mineral supplement on the mineral and sodium intake as well as average daily gain by steers.

\begin{tabular}{|c|c|c|c|c|c|}
\hline \multirow{2}{*}{$\begin{array}{l}(\%) \mathrm{NaCl} \text { In } \\
\text { the Mix }\end{array}$} & \multirow{2}{*}{$\begin{array}{c}\text { Mineral/ } \\
\text { Head/ Day (g) }\end{array}$} & \multirow{2}{*}{$\begin{array}{l}\mathrm{Na} / \text { Head/Day } \\
\text { (Average) (g) }\end{array}$} & \multicolumn{2}{|c|}{ Liveweight (kg) } & \multirow{2}{*}{$\begin{array}{l}\text { Average Daily } \\
\text { Gain }(\mathrm{kg})\end{array}$} \\
\hline & & & Initial & Final & \\
\hline 100 & $37 \pm 10 b c$ & 14.5 & 330.2 & 367.7 & 0.4121 \\
\hline 80 & $41 \pm 6 b$ & 12.9 & 333.7 & 372.6 & $0.427 \mathrm{kl}$ \\
\hline 60 & $43 \pm 8 b$ & 10.1 & 329.4 & 369.4 & $0.439 \mathrm{k}$ \\
\hline 40 & $56 \pm 7 \mathrm{a}$ & 7.4 & 324.9 & 368.11 & $0.475 \mathrm{k}$ \\
\hline 20 & $27 \pm 13 c$ & 2.1 & 338.3 & 373.4 & 0.3961 \\
\hline
\end{tabular}

Means in the same column with different letters are significantly different $(\mathrm{p}<0.05)$.

mineral mix. PAMP et al (1976) reviewed the practice of feeding minerals free choice to ruminants and concluded that these animals have not a specific appetite for calcium or phosphorus even when they were fed a ration low in these elements. Moreover, these authors stated that in some cases high levels of dicalcium phosphate in the mix could depress the consumption of the mineral supplement by cattle. Another possibility

\section{DISCUSSION}

The results of the first experiment clearly showed the influence of the ratio of common salt to mineral mix on the consumption of mineral supplement with some implication on the average daily gain (table 2). Undoubtedly, sodium content in the mineral supplement controlled its voluntary intake by cattle as far as the sodium requirements were completely or partially satisfied. According to MORRIS (1980), grazing beef cattle require a diet with 0.06 to $0.08 \%$ of sodium for adequate growth. A $350 \mathrm{~kg}$ growing steer should receive at least $6.3 \mathrm{~g}$ of dietary sodium daily. The pastures offered to the steers, in the first experiment, only $16.7 \%$ of the required sodium (table 1 ). Thus, at least $5.24 \mathrm{~g}$ of sodium should be consumed through the mineral supplementation to meet the requirement. Considering the average daily consumption of sodium contained in the mineral supplement the steers receiving decreasing amount of sodium in the supplement, principally the $40 \%$ common saltgiloap,tohinges lamgestahaogert amount of mineral of mineral supplement to reach the sodium requirement. Nevertheless, the $20 \%$ common salt-group had the lowest mineral intake and the amount of sodium ingested $(2.1 \mathrm{~g} /$ head/day) was not enough to meet the requirement, thus those steers could present sodium deficiency after receiving this mineral supplement for a long period. It is speculated that this low mineral intake was caused by higher levels of dicalcium phosphate in the
Table 3 - Influence of the form which the mineral supplement is offered on the mineral intake and the average daily gain (ADG) of steers.

\begin{tabular}{|c|c|c|c|c|c|}
\hline \multirow{2}{*}{$\begin{array}{l}\text { Form of the } \\
\text { Mineral }\end{array}$} & \multirow{2}{*}{$\begin{array}{c}\text { Consump- } \\
\text { tion/Head/Day (g) }\end{array}$} & \multirow[t]{2}{*}{ C.V.\# (g) } & \multicolumn{2}{|c|}{ Liveweight (kg) } & \multirow[t]{2}{*}{$\mathrm{ADG}(\mathrm{kg})$} \\
\hline & & & Initial & Final & \\
\hline Loose & $60 \pm 5 \mathrm{a} * *$ & 8.33 & 383.5 & 430.8 & $0.520 \mathrm{a}^{*}$ \\
\hline Partially Blocked & $45 \pm 12 b$ & 27.7 & 375.9 & 420.2 & $0.487 \mathrm{~b}$ \\
\hline Hard Block & $27 \pm 15 \mathrm{c}$ & 55.6 & 387.3 & 428.7 & $0.455 \mathrm{c}$ \\
\hline
\end{tabular}

Means in the same column with different letters are significantly different $(* \mathrm{p}<0.05)$

$(* * \mathrm{p}<0.01)$; \# Coefficient of Variation. of low mineral intake by steers receiving $20 \%$ of common salt could be the small amount of sodium chloride in the supplement not enough to stimulate the mineral intake. DEW et al (1954) allowed dairy cows free access to various mixtures of sodium chloride and steamed bone meal and the cattle showed preference for mixtures with high sodium chloride content. Even though the use of supplements with low $\mathrm{NaCl} /$ mineral mix ratio to cattle is uncommon to be found on practical condition. CAVALHEIRO \& TRINDADE (1992) determined the $\mathrm{NaCl}$ content in many mineral supplements as offered to beef and dairy cattle raised in brazilian farms. They found only $4 \%$ of the mineral samples with $20 \%$ or less of $\mathrm{NaCl}$.

As a $350 \mathrm{~kg}$ growing steer requires $6.3 \mathrm{~g}$ of sodium daily (MORRIS, 1980), the steers that received four out five mineral supplements ( $100 \%$, $80 \%, 60 \%$ and $40 \% \mathrm{NaCl}$ groups) consumed more sodium than their requirements (table 2). MICHELL (1985) stated that normal appetite of cattle for 
sodium far exceeds their sodium requirements and the exuberant consumption of common salt is not, therefore, indicative of actual need.

The $\mathrm{NaCl}$ is the principal ingredient that stimulates or controls the mineral intake by cattle. CAVALHEIRO \& TRINDADE (1992) stated that normal cattle, usually, loose the appetite for a mineral supplement when $27 \mathrm{~g}$ of common salt is ingested in 24 hours. The daily intake of common salt by steers receiving $80 \% \mathrm{NaCl}$ in the supplement (33g) was higher than the upper limit stated by the latter authors indicating that the maximum intake of common salt in mineral supplement by cattle depends on its ratio of dilution.

The steers that received mineral supplements with $40 \%$ and $60 \%$ of $\mathrm{NaCl}$ had a higher average daily gain than the $100 \% \mathrm{NaCl}$ group (table 2). This result clearly shows the direct effect of the supplementation of several macro $(\mathrm{P}, \mathrm{Ca}, \mathrm{S}$ and $\mathrm{Mg})$ and microelements $(\mathrm{Cu}, \mathrm{Zn}, \mathrm{Fe}, \mathrm{Mn}, \mathrm{Co}, \mathrm{I}$ and $\mathrm{Se}$ ), other than sodium and chloride, on the steers' performance. SOUSA et al. (1983) also verified a higher average daily gain of steers kept on pastures of guinea grass (Panicum maximum), for 336 days, supplemented with $\mathrm{NaCl}+\mathrm{P}+$ microelements compared to a single offer of $\mathrm{NaCl}$.

In the second experiment, a clear evidence of the form which the mineral supplement is offered on the voluntary intake of mineral by steers is shown (table 2). The harder the mineral supplement offered, the lower its intake by steers. ZHU et al. (1991) prepared supplement blocks based on liquid condensed solubles and dried distillers grains with a range of hardness index. They found that supplement intake by cattle decreased linearly as block hardness increased..

Mineral supplement offered as a block to steers had its content less ingested by $55 \%$ compared to the group that received loose mineral. (table 3). ROCKS et al. (1982) studied the consumption of loose and block mineral by sheep and verified that the mean intake of loose mineral was $8.9 \mathrm{~g} / \mathrm{head} /$ day and that of block mineral $3.8 \mathrm{~g} / \mathrm{head} / \mathrm{day}$. These results contrast markedly with that expressed by McDOWELL et al. (1993) that the consumption of hard block mineral by cattle is reduced only $10 \%$ compared to the loose form.

The coefficient of variation $(\mathrm{CV})$ of the supplement intake increased as supplement hardness increased, averaging $8.3 \%$ for loose mineral, $26.7 \%$ for partially blocked and $55.6 \%$ for hard block (table $3)$. This result shows the variable and inconstant intake of minerals by cattle when the supplement is presented as a hard block. ZHU et al. (1991) also verified an increase in the $\mathrm{CV}$ of supplement intake by cattle as block hardness increased. Under tropical and subtropical conditions it is common to find mineral supplements offered to cattle as a hard block due to the environmental conditions such as high air humidity and heavy rain, principally in the summer when the mineral supplemented is more consumed (McDOWELL et al., 1993). Another condition commonly found in many brazilian farms is the excessive offering of mineral supplement in large feed troughs providing much more salt than the cattle can eat in that time lag, allowing the mineral to become hard as a block.

In conclusion, to stimulate an adequate intake of mineral supplement and to promote higher average daily gain steers should be offered supplements with $40 \%$ and $60 \% \mathrm{NaCl} /$ mineral mix changed weekly in order to avoid the hardening of its content. The higher the hardening of the mineral supplement, the lower is its consumption by steers.

\section{REFERENCES}

ASSOCIATION OF THE OFFICIAL ANALITICAL CHEMISTS. Official and tentative methods of analysis. 6 . ed. Washington: Georg Barita, 1985. 1015 p.

CAVAlHEIRO, A.C.L., TRINDADE, D.S. Os minerais para bovinos e ovinos criados em pastejo. Porto Alegre: Fund. Banco do Brasil, 1992. 142 p.

DEW, M.I. , STODDARD, G.E., BATEMAN, G.Q. Phosphorus supplements made more palatable with salt. Utah Farm Home Sci, v. 39, p. 36 - 42, 1954.

McDOWELL, L.R., CONRAD, J.R., ELLIS, G.L. Mineral deficiencies and imbalances, and their diagnosis. In GILCHRIST, F.M.C.; MACKIE, R.I. Herbivore nutrition in the subtropics and tropics, London: Science, 1984. Cap. 3, p. 64-88.

McDOWELL, L.R., CONRAD, J.H., HEMBRY, F.G. et al. Minerales para rumiantes en pastoreo en regiones tropicales. 2. ed. Gainsville: Agenc. Dessarrollo Intern., 1993, $76 \mathrm{p}$.

MICHELL, A.R, Sodium in health and disease: A comparative review with emphasis on herbivores Vet Rec, v. 116 , p. 653$657,1985$.

MICHELL, A.R, Sodium in health and disease: A comparative review with emphasis on herbivores Vet Rec, v. 116 , p. 653$657,1985$.

MINSON, D.J. Forage in ruminant nutrition. San Diego: Academic, 1990. 483p.

MORRIS, J.G. Assessment of sodium requirements of grazing beef cattle: a review. J Ani Sci, v. 50, n. 1, p. 145-152., 1980.

PAMP, D.E., GOORICH,R.D., MEISKE, J.C. A review of the practice of feeding mineral free choice. World Ani Revi, v. 12, n. 4, p. 13-18, 1976. 
ROCK, R.L., WHEELER, J.L, HEDGES, D.A, Labelled waters of crystallization in gypsum to measure the intake by sheep of loose and compressed mineral supplements. Austr J Exp Agric Ani Husb, v. 22, n. 1, p. 35-42, 1982

SNEDCOR, G.W., COCKRAM, W.G. Statistical methods. 6. ed. Ames: Iowa State University, 1967. 593 p.

SOUSA, J.C., GOMES, R.F.C., RESENDE, A.M. et al. Resposta de novilhos anelorados a suplementação mineral em pastagens de capim-colonião. Pesq Agrop Bras, v. 18, n. 3, p. 311-318, 1983.
TAIT, R.M., FISHER, L.J. Variability in individual animal's intake of minerals offered free-choice to grazing ruminants. Ani Feed Sci Techn, v. 62 ,n. 1, p. 69-76, 1996.

TOKARNIA, C.H., DÖBERAINER, J., MORAES, S.S. Situação atual e perspectivas da investigação sobre nutrição mineral em bovinos no Brasil. Pesq Vet Bras, v. 8, n. 1-2, p.1-16, 1988.

ZHU, X.C.W., DEYOE, K.C., BEHNKE , PA Poured feed blocks using destillary by - products as supplements for ruminants. $\mathbf{J}$ Sci Food Agric, v. 54: p. 534-539, 1991.

Ciência Rural, v. 29, n. 4, 1999. 